\title{
Scenario development
}

\author{
Tanja Hichert, ${ }^{1,2}$ Reinette Biggs, ${ }^{2,3}$ Alta de $\operatorname{Vos}^{4}$ and Garry Peterson ${ }^{3}$ \\ ${ }^{1}$ HICHERT AND ASSOCIATES, SOMERSET WEST, SOUTH AFRICA \\ ${ }^{2}$ CENTRE FOR SUSTAINABILITY TRANSITIONS, STELLENBOSCH UNIVERSITY, STELLENBOSCH, SOUTH AFRICA \\ ${ }^{3}$ STOCKHOLM RESILIENCE CENTRE, STOCKHOLM UNIVERSITY, STOCKHOLM, SWEDEN \\ ${ }^{4}$ DEPARTMENT OF ENVIRONMENTAL SCIENCE, RHODES UNIVERSITY, MAKHANDA, SOUTH AFRICA
}

\section{Key methods discussed in this chapter}

Double uncertainty matrix, Mānoa, scenario archetypes, La Prospective, causal layered analysis

\section{Connections to other chapters}

Scenario development connects to various other methods, but in particular to futures analysis (Chapter 10) as it is also regarded as a futures analysis method. It warrants a separate chapter in addition to the other futures analysis methods (described in Chapter 10) because of its importance and widespread use. Scenario development also connects to facilitated dialogues (Chapter 9), serious games (Chapter 12), participatory modelling and planning (Chapter 13), dynamical systems modelling (Chapter 26) and agent-based modelling (Chapter 28).

\section{Introduction}

Scenario development has a rich history and has been widely used for more than five decades in the corporate and military sectors, from where it originates (Bradfield et al. 2005). Over the past three decades, scenario approaches have been increasingly used in social-ecological systems (SES) research in many different contexts (e.g. for exploring the integrated future of biodiversity, land-use change, ecosystem services, and changes in value systems, global markets and the climate), at scales from local communities to the entire planet (Peterson, Cumming, and Carpenter 2003; Carpenter, Bennett, and Peterson 2006; Oteros-Rozas et al. 2015). Scenario development in global assessments is used to focus scientific investigation, integrate different models and data, and improve decision-making (Kok et al. 2017; Rosa et al. 2017), whereas local-scale scenarios often involve participatory processes that enhance stakeholder engagement and legitimacy in decision-making (Oteros-Rozas et al. 2015).

At their most basic, scenarios are a group of stories, often called narratives, which together describe a range of possible and coherent future worlds for a given system (Curry 2012). Central to scenario development is the concept of exploring multiple, alternative futures. Scenario development never attempts to predict the future, and scenarios never offer a single view of the future (Kosow and Gaßner 2008). Scenario development always focuses on multiple futures. 


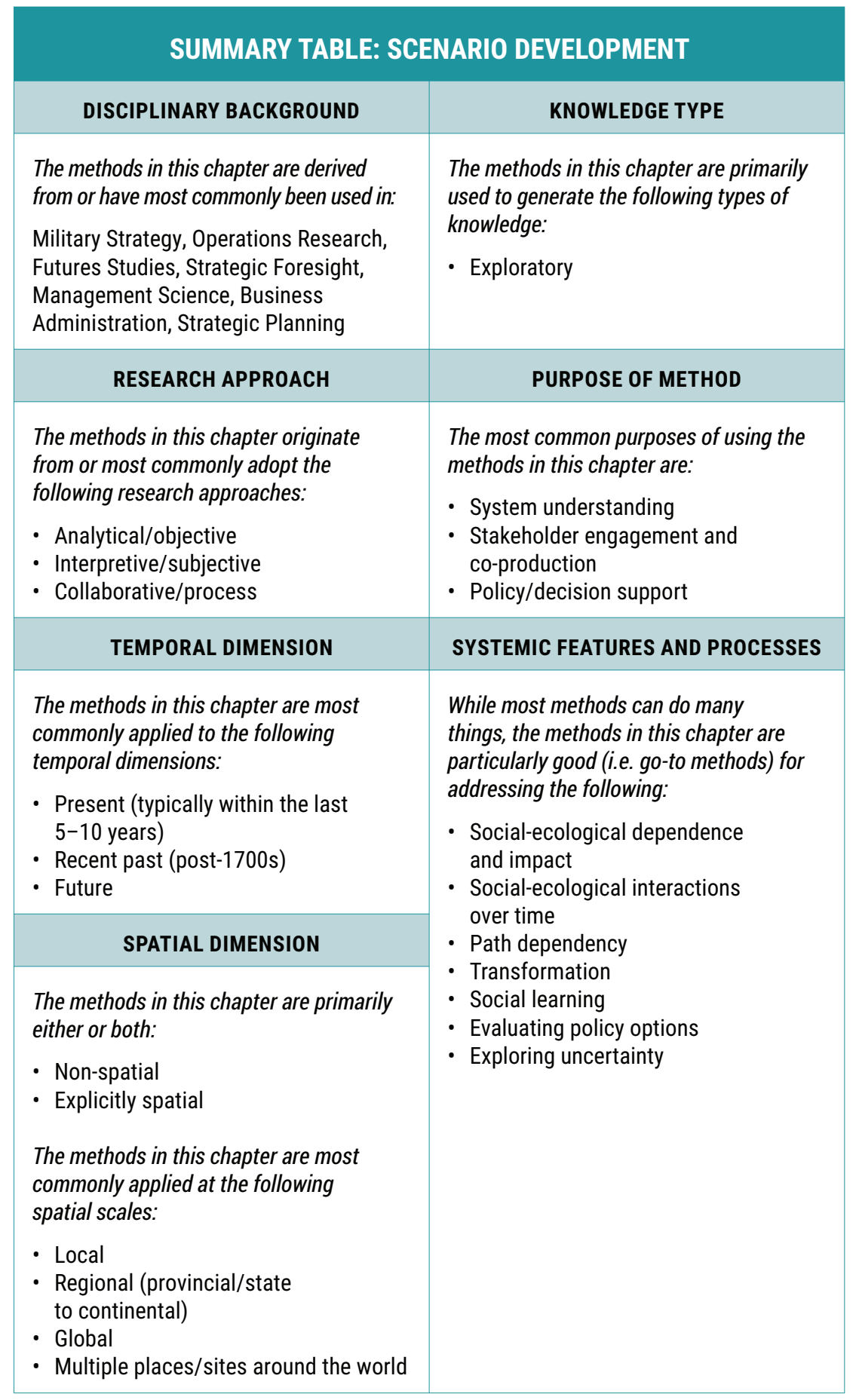


Descriptions and analyses of scenarios typically include terms such as 'plausible', 'possible' and 'preferable' futures (Bishop, Hines, and Collins 2007; Alcamo 2008; Kosow and Gaßner 2008). Importantly, these different futures are not extrapolations or variations around a base case. Rather, each scenario in a set offers a structurally different view of the future, based on different assumptions about groups of key variables that might shape systems change into the future (Bishop, Hines, and Collins 2007; Alcamo 2008; Kosow and Gaßner 2008).

Since scenario development uses narratives to connect sometimes unrelated drivers of change or projections, it can create stories around disconnected and random events. Scenario development can also overemphasise porous system boundaries to enable clear stories to emerge. The real world is full of complex, cross-scale drivers and feedbacks, therefore creating understandable, cohesive yet rich stories is very challenging. However, by incorporating diverse types of knowledge, being flexible and telling stories, scenario construction can inject an appreciation of the variety of possible futures into decision-making, planning and science.

Scenario development is used for decision-making, sense-making and to change mindsets (Bishop, Hines, and Collins 2007). Similar to the futures analysis methods listed in Chapter 10, the overarching aim of scenario development is to 'work' with and 'learn' from reflecting on the future in order to make better decisions and choices in the present because our actions in the present can influence the future (Glenn and Gordon 2009; Kosow and Gaßner 2008). There are many different scenario development approaches, and SES scenarios often involve a combination of qualitative and quantitative methods and tools. Scenarios draw on our scientific understanding of historical patterns, current conditions, physical and social processes, and relationships. They also draw on the imagination to conceive, articulate and evaluate alternative pathways of development and the impacts and interactions of these with the environment (Kosow and Gaßner 2008). This understanding is then used to illuminate links between issues, the relationships between global and regional development, and the role of human actions in shaping the future (Raskin and Kemp-Benedict 2004).

\section{SES problems and questions}

Scenario planning methods typically share a combination of the following main objectives (Wright, Bradfield, and Cairns 2013):

- To increase our understanding of the consequences of interactions and interrelations in a system, including causal processes (e.g. what are the impacts of different development futures on various ecosystem services and human well-being? (MA 2005))

- To challenge prevailing or entrenched thinking and reframe perceptions, potentially changing the mindsets of decision-makers (participants) (e.g. what current small-scale initiatives or innovations could potentially radically reshape the future way in which the world works? (Bennett et al. 2016; Pereira et al. 2018))

- To improve decision-making with a view to better strategy and policy development (e.g. what policies or strategies are robust in a variety of different potential futures? (Rosa et al. 2017))

An additional objective is to facilitate stakeholder engagement and knowledge co-production in order to draw on and integrate different knowledge types and improve the legitimacy of decision-making (e.g. how can scientific, and indigenous and local knowledge be integrated to better understand the future? (Sandker et al. 2009; Vervoort et al. 2013)).

Social-ecological scenarios can help to clarify, distinguish and explore social-ecological feedbacks, uncertainties and potential surprises, and enable exploration of the dynamics and 
sustainability of SES. The Millennium Ecosystem Assessment (MA) scenarios, for example, involved a combination of narrative storylines and detailed quantitative models to explore the future of a wide range of ecosystem services and their implications for human well-being, at local, regional and global scales (MA 2005). Scenarios can also be used to explore important cross-scale processes and feedbacks that link local, regional and global scales (Rosa et al. 2017).

Scenarios can enable inclusive, participatory, dialogue-stimulating processes that are essential for exploring the normative dimensions of sustainable development. Participatory scenario processes are extensively used in SES research and can enhance stakeholder engagement in decision-making processes (Oteros-Rozas et al. 2015). These processes allow for the integration of stakeholder views and increase the relevance, acceptance and legitimacy of scenario findings (Kok, Biggs, and Zurek 2007). Participatory scenarios can also provide an important avenue for integrating practitioner, indigenous and local knowledge with scientific knowledge, which can fill important information gaps, increase agency and empower stakeholders (Tengö et al. 2014; IPBES 2016; Bourgeois et al. 2017; Falardeau, Raudsepp-Hearne, and Bennett 2018). Scenario development can therefore contribute to dealing with the methodological challenges of sustainability science by linking local and global perspectives and accounting for temporal inertia and urgency. This can be done by linking long-term goals; highlighting complex linkages, multiple stressors and inconsistencies; and revealing links among disciplines, themes and issues (Swart, Raskin, and Robinson 2004).

Scenario development can help to identify novel lines of enquiry and challenge existing assumptions about how the world works (Ramirez et al. 2015). The Mānoa mash-up method, for example, explores how a variety of technological and social innovations may come together to change the current major driving forces of change in the world (Pereira et al. 2018; Raudsepp-Hearne et al. 2019). Multiple alternative futures can be used to 'stress-test' or screen strategic objectives, plans, policies and projects to see whether they will perform well under different possible futures. It is often found that plans and policies become obsolete or fail if the future does not turn out as expected (Enfors et al. 2008). The exercise to determine how future changes might affect the ability to deliver a set of strategic objectives, plans or policies is called 'wind tunnelling'.

Different types of scenario processes can address the needs of alternative policy and decision contexts (IPBES 2016, Figure 5.1). The policy process can be considered as consisting of agenda-setting, policy-design, implementation and evaluation contexts. While bridging different perspectives is particularly important in agenda-setting contexts, evaluating alternatives is particularly important in policy-design contexts. Exploratory scenarios examine a range of plausible futures based on potential trajectories of key drivers and can contribute significantly to understanding system dynamics, high-level problem identification and agenda setting. In contrast, intervention scenarios focus on informing policy design and implementation by evaluating alternative policy or management options (IPBES 2016).

\section{Brief description of key methods}

Many different approaches to scenario development exist, including participatory, expert-driven, qualitative, quantitative and hybrid approaches. 'Participatory' here refers specifically to collaborative scenario processes that involve directly affected stakeholders. Participatory scenario development can be exclusively qualitative, but often involves hybrid approaches that use a combination of qualitative and quantitative approaches (Oteros-Rozas et al. 2015). In hybrid approaches, scenario storylines are often initially developed using qualitative approaches and then used to parameterise one or more models to explore the outcomes and 
check for plausibility, which may then feed back into revising the scenario storyline (Alcamo, Van Vuuren, and Ringler 2005). These story and simulation approaches may involve a wide variety of different modelling approaches, including integrated assessment models, agent-based models (Chapter 28), state-and-transition models (Chapter 27) and dynamical systems modelling (Chapter 26), and draw on various participatory modelling approaches (Chapter 13). Protocols that deal with the challenges of converting 'narrative' to 'numbers' in these hybrid scenarios include methods such as cross-impact balance and simulation (CIBAS) (Kosow 2011) and fuzzy cognitive mapping (FCM) (Kok 2009). In contrast to participatory scenarios, expert-driven scenarios are created with only expert input. Although these scenarios may involve qualitative aspects, they tend to focus on quantitative model-based exercises.

Within these broader categories, there is a range of methods for developing scenarios (Glenn and Gordon 2009). By far the most popular and well-known approach is the ' $2 \times 2$ double uncertainty matrix'. Other methods include scenario archetypes, Mānoa scenario building, La Prospective, which involves morphological scenarios (also known as field anomaly relaxation or FAR), causal layered analysis and new developments where methods are combined (Table 11.1). These methods range from 'harder', more technically oriented approaches to 'softer', more intuitive methods and from those focused more on structure to those focused more on values (Curry 2012).

Table 11.1 Summary of key scenario development approaches most commonly used in SES research

\begin{tabular}{|c|c|c|}
\hline Approach & Description & References \\
\hline $\begin{array}{l}\text { Quantitative } \\
\text { scenarios }\end{array}$ & $\begin{array}{l}\text { Quantitative scenarios rely on quantitative simulation } \\
\text { models to generate plausible outcomes under different } \\
\text { simulated conditions. }\end{array}$ & $\begin{array}{l}\text { Key introductory text } \\
\text { Popper } 2008 \\
\text { Applications to SES } \\
\text { Nelson } 2005\end{array}$ \\
\hline $\begin{array}{l}\text { Participatory } \\
\text { scenarios }\end{array}$ & $\begin{array}{l}\text { Participatory scenarios can use a variety of exclusively } \\
\text { qualitative methods, but more often use a hybrid } \\
\text { approach (see below) to engage different stakeholders in } \\
\text { the scenario process. }\end{array}$ & $\begin{array}{l}\text { Key introductory text } \\
\text { Popper } 2008 \\
\text { Applications to SES } \\
\text { Palomo et al. } 2011 ; \\
\text { Oteros-Rozas et al. } 2015\end{array}$ \\
\hline $\begin{array}{l}\text { Hybrid } \\
\text { scenarios }\end{array}$ & $\begin{array}{l}\text { Hybrid scenarios, also called the story and simulation } \\
\text { approach (described above), broadly refer to the } \\
\text { combination of qualitative and quantitative scenario } \\
\text { methodologies. }\end{array}$ & $\begin{array}{l}\text { Key introductory texts } \\
\text { Kemp-Benedict 2004; } \\
\text { Kosow } 2011 \\
\text { Applications to SES } \\
\text { Alcamo, Van Vuuren, } \\
\text { and Ringler } 2005\end{array}$ \\
\hline $\begin{array}{l}2 \times 2 \text { double } \\
\text { uncertainty } \\
\text { matrix }\end{array}$ & $\begin{array}{l}\text { The } 2 \times 2 \text { double uncertainty matrix (also known as the GBN } \\
\text { method) is the most common and best-known method. } \\
\text { By brainstorming and analysing key drivers of change - } \\
\text { 'driving forces' of the issue of concern - participants choose } \\
\text { two highest impact, highly uncertain drivers, often after } \\
\text { clustering, and extrapolate them to their opposite extremes } \\
\text { (polarities) to provide four cells representing the kernels } \\
\text { of four alternative futures. These are then elaborated into } \\
\text { alternative stories or images. }\end{array}$ & $\begin{array}{l}\text { Key introductory text } \\
\text { Schwartz } 1991 \\
\text { Applications to SES } \\
\text { Hamann et al. } 2012\end{array}$ \\
\hline
\end{tabular}


Tanja Hichert et al.

Table 11.1 (Continued)

\begin{tabular}{|c|c|c|}
\hline Approach & Description & References \\
\hline $\begin{array}{l}\text { Archetypes or } \\
\text { using existing } \\
\text { scenario sets }\end{array}$ & $\begin{array}{l}\text { The archetype method makes use of generic images of } \\
\text { the future (or existing scenario sets), typically categorised } \\
\text { as Growth, Collapse/New Beginnings, Discipline and } \\
\text { Transform. These archetypal, generic images of the future } \\
\text { are presented to participants who are then asked to add } \\
\text { details to the scenarios, using data and specifics of their } \\
\text { issue of concern. Participants can consider how they would } \\
\text { redefine, reinvent or otherwise transform their objectives, } \\
\text { activities, plans or policies to succeed under each scenario. } \\
\text { The original archetypes were derived from a content analysis } \\
\text { of futures research and other forecasts available in the 1970s. }\end{array}$ & $\begin{array}{l}\text { Key introductory texts } \\
\text { Dator 2009, } 2017 \\
\text { Applications to SES } \\
\text { Carpenter et al. } 2015 \text {; } \\
\text { Sitas et al. } 2019\end{array}$ \\
\hline $\begin{array}{l}\text { The Mānoa } \\
\text { method }\end{array}$ & $\begin{array}{l}\text { The Mānoa method for constructing scenarios is used to } \\
\text { maximise difference from the present. It is usually used to } \\
\text { create exploratory, possible scenarios but can be adapted } \\
\text { for creating preferred, normative scenarios. The Mānoa } \\
\text { method relies on futures wheels, which is a futures } \\
\text { analysis method (see Chapter 10) used for identifying } \\
\text { cascading waves of change and dynamics in the system } \\
\text { under consideration. }\end{array}$ & $\begin{array}{l}\text { Key introductory text } \\
\text { Schultz 2015b } \\
\text { Applications to SES } \\
\text { Pereira et al. 2018; } \\
\text { Hichert, Biggs, and } \\
\text { Preiser } 2019\end{array}$ \\
\hline La Prospective & $\begin{array}{l}\text { La Prospective is a French approach to scenario planning, } \\
\text { encompassing quantitative and qualitative techniques } \\
\text { and relying on computer-based tools to analyse structural } \\
\text { conditions and stakeholder positions. It has a morphological } \\
\text { element (also known as field anomaly relaxation) combined } \\
\text { with a participatory aspect, and has recently been adapted } \\
\text { to develop 'futures literacy' (the capability of 'using' the } \\
\text { future to change the present, to change the future) to } \\
\text { empower grassroots level stakeholders. }\end{array}$ & $\begin{array}{l}\text { Key introductory texts } \\
\text { Godet 1986; } \\
\text { Bourgeois et al. } 2017 \\
\text { Applications to SES } \\
\text { Del Mar Delgado- } \\
\text { Serrano et al. } 2015\end{array}$ \\
\hline $\begin{array}{l}\text { Causal layered } \\
\text { analysis }\end{array}$ & $\begin{array}{l}\text { Causal layered analysis is a futures analysis method } \\
\text { (Chapter 10) that can also be used to generate scenarios. } \\
\text { It translates different ways of knowing into four layers: (a) } \\
\text { 'litany' (the way in which trends and issues are presented } \\
\text { in the public domain), (b) 'systems' (causal and institution- } \\
\text { based understanding), (c) 'worldview', and (d) 'metaphor'. } \\
\text { Scenarios are developed by working through the layers to } \\
\text { worldview and metaphor, then 'inflecting' (fundamentally } \\
\text { changing) them. The scenarios emerge by reinterpreting } \\
\text { the layers through the lens of the deepest level inflection. }\end{array}$ & $\begin{array}{l}\text { Key introductory text } \\
\text { Inayatullah } 2004 \\
\text { Applications to SES } \\
\text { Heinonen et al. } 2017\end{array}$ \\
\hline $\begin{array}{l}\text { Combining } \\
\text { methods }\end{array}$ & $\begin{array}{l}\text { Constructing scenarios is practice based and therefore } \\
\text { constantly evolving and being adapted for specific } \\
\text { purposes. This means methods are increasingly } \\
\text { being combined with one another and other futures/ } \\
\text { foresight tools, methods and approaches (Chapter } \\
\text { 10). This includes combining axes of uncertainty ( } 2 \times 2 \\
\text { double uncertainty matrix) with visioning, causal } \\
\text { layered analysis with gaming, and visionary scenarios } \\
\text { with the three horizons framework and back-casting. }\end{array}$ & $\begin{array}{l}\text { Applications to SES } \\
\text { Heinonen et al. 2017; } \\
\text { Falardeau 2018; } \\
\text { Pereira et al. 2018; } \\
\text { Hichert, Biggs, and } \\
\text { Preiser 2019; } \\
\text { Iwaniec et al. } 2020\end{array}$ \\
\hline
\end{tabular}




\section{Limitations}

Scenario development exists between the rigour of process-based models and the flexibility of stories. As such, some of the strengths of scenario planning are also limitations when viewed from other perspectives. Because scenario development often uses approximations rather than 'exact' inputs, it risks being less extreme or variable than reality itself. Scenarios cannot, and should not, be used for forecasting and/or prediction purposes. In participatory scenarios, a lack of experienced facilitators and flaws in participant selection owing to a lack of diversity, dysfunctional power relations or an inability to take cognitive bias into account can compromise the scenario development process and lead to weak or biased scenarios that do not meet the objectives of the exercise. Participatory processes can be difficult to conduct in situations where there is a lack of trust, extreme power inequality and a lack of resources. In these situations, other approaches may be more fruitful.

Hybrid scenarios - the story and simulation approach - can be problematic owing to differences between qualitative and quantitative methods, levels of stakeholder expertise and attempts to integrate different types of knowledge into the analysis (Wiebe et al. 2018). Converting narrative statements embedded in scenario storylines into quantifiable parameters for numerical modelling can be difficult if the variables addressed in the quantitative versus qualitative processes are quite different. In these situations, the quantitative variables tend to be emphasised at the expense of the intangible or difficult-to-quantify variables (Booth et al. 2016). Davenport et al. (2018) propose a simple analytical framework based on five categories of capital assets as part of a protocol for overcoming the conversion problem in hybrid scenario analysis.

These limitations are easier to address when scenario planning is embedded in ongoing, long-term research processes that already bridge different groups and knowledge systems. These long-term relationships can improve the quality of scenarios, reduce the difficulty of creating them and ensure that they can be more easily connected to policy and decision-making. When scenarios are embedded in an ongoing process, their use and impact are also easier to evaluate.

\section{Resource implications}

Successful hybrid participatory scenario planning exercises, especially those dealing with social-economic systems, rely on seasoned facilitators, process designers, modellers, project coordinators and enough time to integrate diverse types of knowledge, often on an iterative basis. This all adds up to expense. Oteros-Rozas et al. (2015) make good recommendations on how to deal with these challenges by, among others things, building on existing networks and scenario sets.

The quantitative modelling aspect requires access to specialised modelling skills, as well as the hardware and software elements associated with them, whereas the qualitative, participatory aspect relies on skilled facilitators and appropriate stakeholders as participants in workshop settings.

\section{New directions}

Participatory scenario planning methods are constantly evolving and new practices in the broader futures and scenarios fields will continue to spill over into SES research. A number of emerging methods attempt to better incorporate chaos, complexity and tipping points 


\section{Case study 11.1: The development of the Millennium Ecosystem Assessment scenarios}

The goal of the Millennium Ecosystem Assessment (MA) was to provide decisionmakers and stakeholders with scientific information on the links between ecosystem change and human well-being. The MA was ground-breaking in its scope and social-ecological approach (Carpenter et al. 2009). The scenarios component of the MA set out to use creative thinking and storytelling, combined with quantitative modelling of drivers and trends, to develop potential global futures of ecosystem change and human well-being.

The development of the MA scenarios at the global level involved three core phases: (a) organisation, (b) scenario storyline and quantification, and (c) synthesis, review and dissemination (Alcamo, Van Vuuren, and Ringler 2005). The first phase involved establishing a scenario guidance team, a scenario panel, conducting interviews with scenario end-users, determining the objectives and focus of the scenarios, and devising the focal questions of the scenarios. For the MA, the guiding question was identified as: 'What are the consequences of plausible changes in development paths for ecosystems and their services over the next 50 years and what will be the consequences of those changes for human well-being?' (Alcamo, Van Vuuren, and Ringler 2005). This broader question was then focused around four key themes relating to economic and human development, local and regional safety and protection, the use of technologies, and adaptive management and learning about the consequences of management interventions for ecosystem services.

In the second phase, the MA's storyline teams constructed a zero-order draft of scenario storylines based on the key guiding questions and a review and evaluation of past scenario efforts (Raskin 2005). At the same time, a team of modellers was organised to quantify the scenarios. Five global models covering global change processes and provisioning ecosystem services, and two models describing changes in biodiversity, were chosen. Test calculations were carried out. After several iterations, the zero-order storylines were adjusted and cross-checked for internal consistency. These zero-draft scenarios allowed the modelling team, in consultation with the storyline team, to set quantitative levels of key driving forces consistent with the storylines (Nelson 2005). These driving forces included both indirect drivers (demographic, economic, cultural and religious, socio-political, science and technology drivers) and direct drivers (climate variability and change, plant nutrient use, land conversion, biological invasions and diseases) of ecosystem change. Based on the subsequent model outcomes, and a number of feedback workshops with the MA board and stakeholder groups, the storylines were further iterated and focused into first-order storylines. These iterated storylines were then used to inform the revision of model inputs, after which the models were rerun to analyse impacts on ecosystem services and human well-being.

In the final phase, the global scenarios (both qualitative storylines and quantitative modelling calculations) were distributed for general review. Feedback from this process, which included presentations, workshops and the MA review process, were incorporated into the final published version of the storylines and their associated models. Four scenarios emerged from the analysis (MA 2005, Figure 1). Three of the four scenarios suggested that significant changes in policies and institutions can mitigate some of the negative consequences of anthropogenic pressures on the planet. Despite limitations, the MA scenarios influenced many policy processes, conventions 
and businesses at global and regional scales, and represent a landmark change in the way global change assessments engage with futures methods (Reid and Mooney 2016).

A particular challenge for the MA was the multi-scale nature of the relationships between ecosystem services and human well-being. This was addressed through assessments at different spatial scales. Many of the MA regional assessments developed their own scenarios, which were linked to the global scenarios by incorporating some of the global storylines into regional processes, having members of the global team participate in regional assessments and developing regional storylines for the global archetypes (Alcamo, Van Vuuren, and Ringler 2005).

The MA developed four global-scale scenarios that had a landmark impact on understanding long-term social-ecological change (Figure 11.1). The 'Global orchestration' scenario depicted a highly connected world with well-developed global markets and supranational institutions that deal with environmental problems. In the 'Order from strength' scenario, the world is disconnected, fragmented and individualised, with an emphasis on security and the protection of regional economies. In the 'Adapting mosaic' scenario, discredited global institutions have been replaced by stronger local institutions aimed at improving local ecosystem management. In the 'TechnoGarden' scenario, ecosystem services are often delivered by engineered and highly managed systems, some of which have unintended consequences such as the loss of local culture, customs and traditional knowledge.

Figure 11.1 shows the net change in the number of ecosystem services enhanced or degraded under each of the four scenarios, for each of the four ecosystem service categories. A $100 \%$ degradation or enhancement score means all the services in that category would be degraded or enhanced by 2050 .

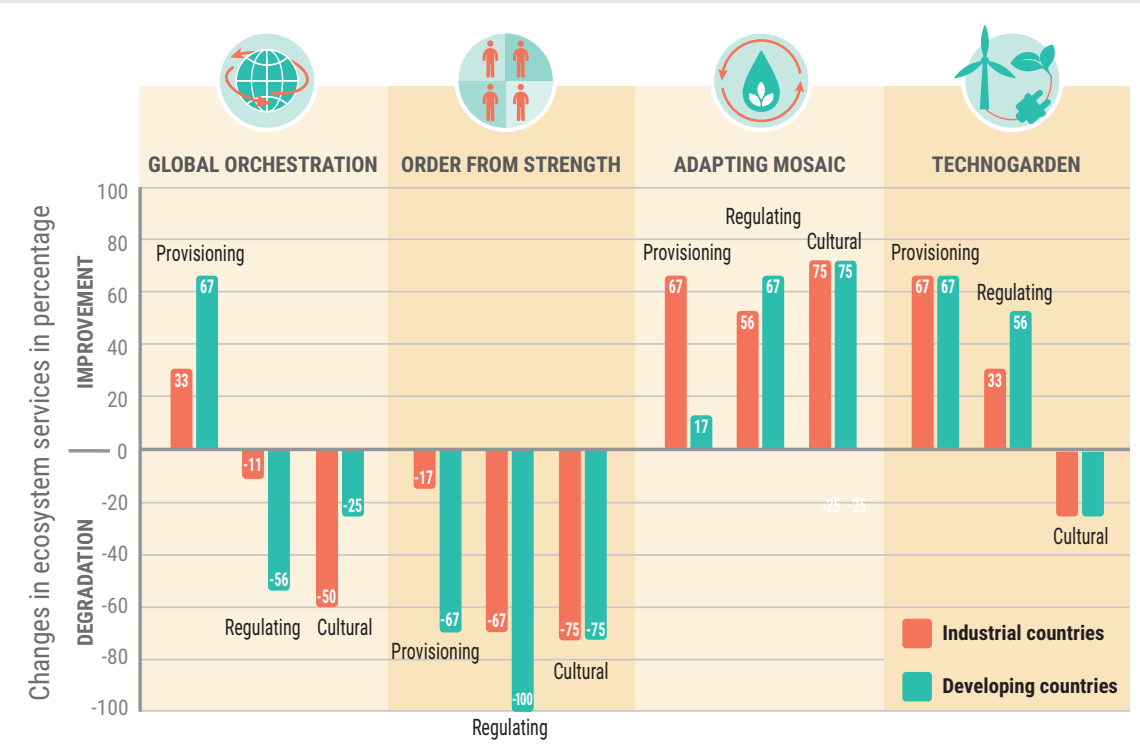

Figure 11.1 Net change in the number of ecosystem services enhanced or degraded under each of the four scenarios, for each of the four ecosystem service categories (๑ Millennium Ecosystem Assessment 2005) 
(black swan type surprises or wildcards) (e.g. Hamann et al. 2012). In the field of futures studies, concepts such as 'crazy futures' (Schultz 2015a), 'preposterous futures' (Voros 2017) and 'post-normal times' (Sardar and Sweeney 2016) are expected to influence existing methods and inspire new ones.

Innovative and creative practices around combining different scenario methods and/or the mashing up of scenarios and foresight methods are also expected to grow. This includes incorporating activities and practices such as gaming, design, art and virtual reality.

Experiential scenarios (Candy 2010), science-fiction prototyping (Merrie et al. 2018) and scenarios based on crowdsourcing, using tools such as SenseMaker (sensemaker.cognitiveedge.com) and Futurscaper (futurescaper.com) (Raford 2012), are emerging methods and practices that hold particular promise for the SES field.

Finally, expanding the number of people able to participate in scenario processes can have great potential. Most participatory scenarios involve relatively small groups of people. However, there have been experiments with massive online scenarios that have the potential to include many more voices (McGonigal 2011). Developing new scenario methods that enable large-scale participation could be very useful in incorporating teleconnections and plurality, and creating more radical futures to explore the interconnected world of the Anthropocene.

\section{Key readings}

Alcamo, J. 2008. 'Environmental Futures: The Practice of Environmental Scenario Analysis.' Developments in Integrated Environmental Assessment, Volume 2. Amsterdam: Elsevier. doi:10.1016/ S1574-101X(08)00406-7.

Bishop, P., A. Hines, and T. Collins. 2007. 'The Current State of Scenario Development: An Overview of Techniques.' Foresight 9(1): 5-25.

Curry, A. 2012. 'The Scenarios Question.' In The Future of Futures, edited by A. Curry. Houston: Association of Professional Futurists.

Glenn,J.C., and T.J. Gordon. 2009. Futures Research Methods 3.0. Millennium Project. www.millenniumproject.org/publications-2/futures-research-methodology-version-3-0.

Kosow, H., and R. Gaßner. 2008. Methods of Future and Scenario Analysis: Overview, Assessment, and Selection Criteria, Volume 39. In Studies from German Development Institute/Deutsches Institut für Entwicklungspolitik (DIE). edoc.vifapol.de/opus/volltexte/2013/4381/pdf/Studies_39.2008.pdf.

\section{References}

Alcamo, J. 2008. 'Environmental Futures: The Practice of Environmental Scenario Analysis.' Developments in Integrated Environmental Assessment, Volume 2. Amsterdam: Elsevier. doi:10.1016/ S1574-101X(08)00406-7.

Alcamo, J., D. van Vuuren, and C. Ringler. 2005. Methodology for Developing the MA Scenarios. Millennium Ecosystem Assessment. Ecosystems and Human Well-being: Scenario Assessment. Washington: Island Press.

Bennett, E.M., M. Solan, R. Biggs, T. McPhearson, A.V. Norström, P. Olsson, S.R. Carpenter et al. 2016. 'Bright Spots: Seeds of a Good Anthropocene.' Frontiers in Ecology and the Environment 14(8): 441-448.

Bishop, P., A. Hines, and T. Collins. 2007. 'The Current State of Scenario Development: An Overview of Techniques.' Foresight 9(1): 5-25.

Booth, E.G., J. Qiu, S.R. Carpenter, J. Schatz, X. Chen, C.J. Kucharik, S.P. Loheide II et al. 2016. 'From Qualitative to Quantitative Environmental Scenarios: Translating Storylines into Biophysical Modeling Inputs at the Watershed Scale.' Environmental Modelling and Software 85: 80-97. doi:10.1016/j.envsoft.2016.08.008.

Bourgeois, R., E. Penunia, S. Bisht, and D. Boruk. 2017. 'Foresight for All: Co-elaborative Scenario Building and Empowerment.' Technological Forecasting and Social Change 124: 178-188. 
Bradfield, R., G. Wright, G. Burt, G. Cairns, and K. van der Heijden. 2005. 'The Origins and Evolution of Scenario Techniques in Long Range Business Planning.' Futures 37(8): 795-812.

Candy, S. 2010. The Futures of Everyday Life: Politics and the Design of Experiential Scenarios. PhD diss., University of Hawaii at Mānoa.

Carpenter, S.R., E.M. Bennett, and G.D. Peterson. 2006. 'Scenarios for Ecosystem Services: An Overview.' Ecology and Society 11(1): 29. www.ecologyandsociety.org/vol11/iss1/art29/.

Carpenter, S.R., E.G. Booth, S. Gillon, C.J. Kucharik, S. Loheide, A.S. Mase, M. Motew et al. 2015. 'Plausible Futures of a Social-Ecological System: Yahara Watershed, Wisconsin, USA.' Ecology and Society 20(2): 10. doi:10.5751/ES-07433-200210.

Carpenter, S.R., H.A. Mooney, J. Agard, D. Capistrano, R.S. deFries, S. Díaz, T. Dietz et al. 2009. 'Science for Managing Ecosystem Services: Beyond the Millennium Ecosystem Assessment.' Proceedings of the National Academy of Sciences 106(5): 1305-1312.

Curry, A. 2012. 'The Scenarios Question.' In The Future of Futures, edited by A. Curry. Houston: Association of Professional Futurists.

Dator, J. 2009. 'Alternative Futures at the Mānoa School.' Journal of Futures Studies 14(2): 1-18.

Dator, J. 2017. 'Some Sources of the Generic Four Alternative Images of the Futures of the Mānoa School.' Design Develop Transform Conference, Antwerp. https://ddtconference.files.wordpress. com/2016/06/dator-sourcesfourfutures.pdf.

Davenport, M., M. Delport, J.N. Blignaut, T. Hichert, and G. van der Burgh. 2018. 'Combining Theory and Wisdom in Pragmatic, Scenario-based Decision Support for Sustainable Development.' Journal of Environmental Planning and Management 62(4): 692-716.

Del Mar Delgado-Serrano, M., E. Oteros-Rozas, P. Vanwildemeersch, C. Ortíz-Guerrero, S. London, and R. Escalante. 2015. 'Local Perceptions on Social-Ecological Dynamics in Latin America in Three Community-based Natural Resource Management Systems.' Ecology and Society 20(4): 24. doi:10.5751/ES-07965-200424.

Enfors, E.I., L.J. Gordon, G.D. Peterson, and D. Bossio. 2008. 'Making Investments in Dryland Development Work: Participatory Scenario Planning in the Makanya Catchment, Tanzania.' Ecology and Society 13(2): 42.

Falardeau, M., C. Raudsepp-Hearne, and E.M. Bennett. 2018. 'A Novel Approach for Co-producing Positive Scenarios that Explore Agency: Case Study from the Canadian Arctic.' Sustainability Science August: $1-16$.

Glenn, J.C., and T.J. Gordon, eds. 2009. Futures Research Methodology Version 3.0. The Millennium Project. www.millennium-project.org/publications-2/futures-research-methodology-version-3-0.

Godet, M. 1986. 'Introduction to La Prospective.' Futures 18: 134-157. doi:10.1016/0016-3287(86) 90094-7.

Hamann, M., V. Masterson, R. Biggs, M. Tengö, B. Reyers, L. Dziba, and M.J. Spierenburg. 2012. 'Social-Ecological Scenarios for the Eastern Cape Province, South Africa 2012-2050.' https:// sapecs.org/wp-content/uploads/2013/08/Eastern-Cape-Scenarios-Report-Aug-2012_-final.pdf.

Heinonen, S., M. Minkkinen, J. Karjalainen, and S. Inayatullah. 2017. 'Testing Transformative Energy Scenarios Through Causal Layered Analysis Gaming.' Technological Forecasting and Social Change 124: 101-113.

Hichert, T., R. Biggs, and R. Preiser. 2019. Generating Visions of Good Anthropocenes: The Mānoa Mash-up Scenarios Methodology. CST Toolkit. University of Stellenbosch. www0.sun.ac.za/cst/publication/ generating-visions-of-good-anthropocenes-the-manoa-mash-up-scenarios-methodology/.

Inayatullah, S. 2004. 'Causal Layered Analysis: Theory, Historical Context, and Case Studies.' In The Causal Layered Analysis (CLA) Reader, edited by S. Inayatullah. Taipei: Tamkang University.

IPBES. 2016. Summary for Policymakers of the Methodological Assessment of Scenarios and Models of Biodiversity and Ecosystem Services of the Intergovernmental Science-Policy Platform on Biodiversity and Ecosystem Services. Edited by S. Ferrier, K.N. Ninan, P. Leadley, R. Alkemade, L.A. Acosta, H.R. Akçakaya, L. Brotons et al. Secretariat of the Intergovernmental Science-Policy Platform on Biodiversity and Ecosystem Services, Bonn, Germany. www.ipbes.net/sites/default/files/downloads/pdf/spm_ deliverable_3c_scenarios_20161124.pdf.

Iwaniec, D.M., E.M. Cook, M.J. Davidson, M. Berbés-Blázquez, M. Georgescu, E.S. Krayenhoff, A. Middel, D.A. Sampson, and N.B. Grimm. 2020. 'The Co-production of Sustainable Future Scenarios.' Landscape and Urban Planning 197: 103744.

Kemp-Benedict, E. 2004. 'From Narrative to Number: A Role for Quantitative Models in Scenario Analysis.' In iEMSs 2004 International Congress: Complexity and Integrated Resources Management, 
edited by C. Pahl-Wostl, S. Schmidt, and T. Jakeman, 765-770. Osnabrück: International Environmental Modelling and Software Society.

Kok, K. 2009. 'The Potential of Fuzzy Cognitive Maps for Semi-Quantitative Scenario Development, with an Example from Brazil.' Global Environmental Change 19: 122-133. doi:10.1016/j. gloenvcha.2008.08.003.

Kok, K., R. Biggs, and M. Zurek. 2007. 'Methods for Developing Multiscale Participatory Scenarios: Insights from Southern Africa and Europe.' Ecology and Society 12(1): 8.

Kok, M.T., K. Kok, G.D. Peterson, R. Hill, J. Agard, and S.R. Carpenter. 2017. 'Biodiversity and Ecosystem Services Require IPBES to Take Novel Approach to Scenarios.' Sustainability Science 12(1): 177-181.

Kosow, H. 2011. 'Consistent Context Scenarios: A New Approach to Story and Simulation.' Paper presented at the 4th International Seville Conference on Future-Oriented Technology Analysis (FTA): FTA and Grand Societal Challenges - Shaping and Driving Structural and Systemic Transformations, Seville, May 2011.

Kosow, H., and R. Gaßner. 2008. Methods of Future and Scenario Analysis: Overview, Assessment, and Selection Criteria, Volume 39. In Studies from German Development Institute/Deutsches Institut für Entwicklungspolitik (DIE). edoc.vifapol.de/opus/volltexte/2013/4381/pdf/Studies_39.2008.pdf.

MA (Millennium Ecosystem Assessment). 2005. Ecosystems and Human Well-Being: Scenarios, edited by S.R. Carpenter, P.L. Pingali, E.M. Bennett, and M.B. Zurek. Washington: Island Press.

McGonigal, J. 2011. Reality is Broken: Why Games Make Us Better and How They Can Change the World. London: Penguin.

Merrie, A., P. Keys, M. Metian, and H. Österblom. 2018. 'Radical Ocean Futures-scenario Development Using Science Fiction Prototyping.' Futures 95: 22-32.

Nelson, G. 2005. 'Drivers of Change in Ecosystem Condition and Services.' Millennium Ecosystem Assessment. Ecosystems and Human Well-Being: Scenario Assessment. Washington: Island Press.

Oteros-Rozas, E., B. Martín-López, T. Daw, E.L. Bohensky, J. Butler, R. Hill, J. Martin-Ortega et al. 2015. 'Participatory Scenario Planning in Place-based Social-Ecological Research: Insights and Experiences from 23 Case Studies.' Ecology and Society 20(4): 32. doi:10.5751/ES-07985-200432.

Palomo, I., B. Martín-López, C. López-Santiago, and C. Montes. 2011. 'Participatory Scenario Planning for Protected Areas Management under the Ecosystem Services Framework: The Doñana Social-Ecological System in Southwestern Spain.' Ecology and Society 16(1): 23.

Pereira, L., T. Hichert, M. Hamann, R. Preiser, and R. Biggs. 2018. 'Using Futures Methods to Create Transformative Spaces: Visions of a Good Anthropocene in Southern Africa.' Ecology and Society 23(1): 19.

Peterson, G.D., G.S. Cumming, and S.R. Carpenter. 2003. 'Scenario Planning: A Tool for Conservation in an Uncertain World.' Conservation Biology 17(2): 358-366.

Popper, R. 2008. 'Foresight Methodology.' In The Handbook of Technology Foresight: Concepts and Practices, edited by L. Georghiou, J. Cassingena Harper, M. Keenan, I. Miles, and R. Popper, 44-88. Cheltenham: Edward Elgar.

Raford, N. 2012. 'Crowdsourced Futures.' In The Future of Futures, edited by A. Curry. Houston: Association of Professional Futurists.

Ramirez, R., M. Mukherjee, S. Vezzoli, and A.M. Kramer. 2015. 'Scenarios as a Scholarly Methodology to Produce "Interesting Research".' Futures 71: 70-87.

Raskin, P.D. 2005. 'Global Scenarios: Background Review for the Millennium Ecosystem Assessment.' Ecosystems 8(2): 133-142.

Raskin, P.D., and E. Kemp-Benedict. 2004. Global Environment Outlook Scenario Framework. United Nations Environment Programme.

Raudsepp-Hearne, C., G.D. Peterson, E.M. Bennett, R. Biggs, A.V. Norström, L. Pereira, J. Vervoort et al. 2019. 'Seeds of Good Anthropocenes: Developing Sustainability Scenarios for Northern Europe.' Sustainability Science. doi:10.1007/s11625-019-00714-8.

Reid, W.V., and H.A. Mooney. 2016. 'The Millennium Ecosystem Assessment: Testing the Limits of Interdisciplinary and Multi-scale Science.' Current Opinion in Environmental Sustainability 19: 40-46.

Rosa, I.M., H.M. Pereira, S. Ferrier, R. Alkemade, L.A. Acosta, H.R. Akcakaya, E. den Belder et al. 2017. 'Multiscale Scenarios for Nature Futures.' Nature Ecology and Evolution 1(10): 1416-1419.

Sandker, M., B.M. Campbell, Z. Nzooh, T. Sunderland, V. Amougou, L. Defo, and J. Sayer. 2009. 'Exploring the Effectiveness of Integrated Conservation and Development Interventions in a Central African Forest Landscape.' Biodiversity and Conservation 18(11): 2875-2892. 
Sardar, Z., and J.A. Sweeney. 2016. 'The Three Tomorrows of Postnormal Times.' Futures 75: 1-13.

Schultz, W.L. 2015a. Crazy Futures: Why Plausibility is Maladaptive. doi:10.13140/RG.2.1.2897.9921

Schultz, W. 2015b. Mānoa: The Future is Not Binary. APF Compass, Methods Anthology Special Edition, 22-26 April 2015.

Schwartz, P. 1991. The Art of the Long View. New York: Doubleday.

Sitas N., Z.V. Harmáčková, J.A. Anticamara, A. Arneth, R. Badola, R. Biggs, R. Blanchard et al. 2019. 'Exploring the Usefulness of Scenario Archetypes in Science-Policy Processes: Experience across IPBES Assessments.' Ecology and Society 24(3): 35.

Swart, R.J., P. Raskin, and J. Robinson. 2004. 'The Problem of the Future: Sustainability Science and Scenario Analysis.' Global Environmental Change 14(2): 137-146.

Tengö, M., E.S. Brondizio, T. Elmqvist, P. Malmer, and M. Spierenburg. 2014. 'Connecting Diverse Knowledge Systems for Enhanced Ecosystem Governance: The Multiple Evidence Base Approach.' Ambio 43(5): 579-591.

Vervoort, J.M., A. Palazzo, D. Mason-D’Croz, P.J. Ericksen, P.K. Thornton, P. Kristjanson, W. Förch et al. 2013. 'The Future of Food Security, Environments and Livelihoods in Eastern Africa: Four Socio-Economic Scenarios.' CCAFS Working Paper No. 63. Copenhagen, Denmark: CGIAR Research Program on Climate Change, Agriculture and Food Security (CCAFS). http://hdl.handle. net/10568/34864.

Voros, J. 2017. 'Big History and Anticipation.' In Handbook of Anticipation: Theoretical and Applied Aspects of the Use of Future in Decision Making, edited by R. Poli, 1-40. New York: Springer.

Wiebe, K., M. Zurek, S. Lord, N. Brzezina, G. Gabrielyan, J. Libertini, A. Loch, R. Thapa-Parajuli, J. Vervoort, and H. Westhoek. 2018. 'Scenario Development and Foresight Analysis: Exploring Options to Inform Choices.' Annual Review of Environment and Resources 43: 545-570.

Wright, G., R. Bradfield, and G. Cairns. 2013. 'Does the Intuitive Logics Method - and its Recent Enhancements - Produce "Effective” Scenarios?' Technological Forecasting and Social Change 80: 631-642. 